This item was submitted to Loughborough's Research Repository by the author.

Items in Figshare are protected by copyright, with all rights reserved, unless otherwise indicated.

\title{
A multi-function compact micro-channel reactor coated with sulphur tolerant catalyst for LPG steam reforming
}

PLEASE CITE THE PUBLISHED VERSION

http://dx.doi.org/10.1002/fuce.201400055

\section{PUBLISHER}

(c) WILEY-VCH Verlag GmbH \& Co.

\section{VERSION}

AM (Accepted Manuscript)

\section{PUBLISHER STATEMENT}

This work is made available according to the conditions of the Creative Commons Attribution-NonCommercialNoDerivatives 4.0 International (CC BY-NC-ND 4.0) licence. Full details of this licence are available at: https://creativecommons.org/licenses/by-nc-nd/4.0/

\section{LICENCE}

CC BY-NC-ND 4.0

\section{REPOSITORY RECORD}

Reed, J., Rui Chen, Christopher D. Dudfield, and Paul L. Adcock. 2015. "A Multi-function Compact Microchannel Reactor Coated with Sulphur Tolerant Catalyst for LPG Steam Reforming”. figshare. https://hdl.handle.net/2134/18433. 


\title{
A Multi-Function CompactMicro-Channel Reactor Coated with Sulphur Tolerant Catalyst for LPG Steam Reforming
}

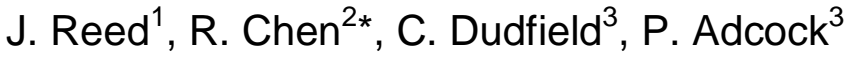 \\ ${ }^{1}$ Sustainable Environment Research Centre,University of SouthWales,UK \\ ${ }^{2}$ Department of Aeronautical and Automotive Engineering, Loughborough University, \\ UK \\ ${ }^{3}$ Intelligent Energy Ltd., UK \\ [] Corresponding author, r.chen@lboro.ac.uk
}

\begin{abstract}
Hydrogen fuelled polymer electrolyte fuel cells (PEFC) offer clear environmental benefits. Lack of viable hydrogen infrastructure in the near future means that a key issue is availability of hydrogen at the point of use. LPG offers advantages as a fuel over other hydrocarbons because there is already an infrastructure in place for remote areas. Hydrogen supply via steam reforming of LPG is therefore a feasible avenue of achieving the environmental benefits. Commercial grade LPG unavoidably contain sulphur as an odorant, the sulphur needs to be removed from the fuel stream before it reaches the reformer catalyst and fuel cell. Utilising sulphur tolerant catalysts in the reformer leads to a simpler fuel processor design. Thermal management and reforming efficiency has been a challenge for the sulphur tolerant catalysts. In this paper, a multi-function compact micro-channel reactor designed for hydrocarbon steam reforming was evaluated for use with LPG. A sulphur tolerant catalyst was washcoated on to the reforming layers. The reformer was tested over a wide range of reactor temperatures, steam to carbon ratios and fuel flow rates. Over $60 \%$ of $\mathrm{H}_{2}$ composition can be achieved at high reforming temperatures with a LPG supply rate of $0.75 \mathrm{dm}^{3} \mathrm{~min}^{-1}$ (STP) and a S/C ratio of 4 .
\end{abstract}

Keywords: Fuel Cell, LPG, Micro-channel, Steam Reforming, Sulphur Tolerant 


\section{Introduction}

Hydrogen is a promising fuel vector for the future. When used together with a polymer electrolyte fuel cell (PEFC) there are clear environmental benefits of using hydrogen as a fuel. As such, the PEFC is seen as a potential clean power plant for various applications. Stationary power and distributed generation in particular are potentially a cost competitive market for the PEFC technology and are therefore seen as early market opportunities [1]. PEFC stacks need a hydrogen stream with a high level of purity (low sulphur and CO levels) to operate effectively [2]. However, a lack of viable infrastructure in the near future means that a key issue is availability of hydrogen at the point of use [3]. The infrastructure to supply hydrocarbon fuels, natural gas or propane is already in place and this has led to interest in the development of small-scale fuel processors that can reform those hydrocarbons into a hydrogen rich fuel [4-7]. Compact fuel reformers are well suited to stationary applications as size and weight limitations are less critical than they would be for mobile/automotive applications [8].

Steam reforming (SR) is a well established method of converting hydrocarbons to a hydrogen rich gas stream. In comparison to partial oxidation or autothermal reforming, steam reforming produces the highest volume of $\mathrm{H}_{2}$ from a given amount of hydrocarbon fuel. $\mathrm{CO}$ is formed by oxidation of the carbon in the fuel with the $\mathrm{O}_{2}$ contained in the steam leaving hydrogen from both the fuel and steam to be released as a gas. Eq. (1) shows the general steam reforming reaction. In a typical steam methane reforming process the water gas shift reaction also occurs, Eq. (2), resulting in a reduction in $\mathrm{CO}$ and the addition of $\mathrm{CO}_{2}$ and further increase inH2 of the products, Eq. (3).

$$
\begin{aligned}
& \mathrm{C}_{\mathrm{n}} \mathrm{H}_{\mathrm{m}}+\mathrm{nH}_{2} \mathrm{O} \rightarrow \mathrm{nCO}+(\mathrm{n}+\mathrm{m} / 2) \mathrm{H}_{2} \\
& \mathrm{CO}+\mathrm{H}_{2} \mathrm{O} \leftrightarrow \mathrm{CO}_{2}+\mathrm{H}_{2} \quad\left(\Delta \mathrm{H}_{298}=-41.16 \mathrm{~kJ} \cdot \mathrm{mol}^{-1}\right) \\
& \mathrm{CH}_{4}+2 \mathrm{H}_{2} \mathrm{O} \leftrightarrow \mathrm{CO}_{2}+4 \mathrm{H}_{2} \quad\left(\Delta \mathrm{H}_{298}=165.12 \mathrm{~kJ} \cdot \mathrm{mol}^{-1}\right)
\end{aligned}
$$

A continuous supply of heat is required to support the endothermic SR reaction usually via a catalytic burner. The reaction temperature is critical since it is a major determinant of the composition of the product gas i.e. the reformate. Also important are the steam to carbon $(\mathrm{S} / \mathrm{C})$ ratio, and operating pressure [6]. At low temperatures and $S / C$ ratio, methanation can occur, resulting in a methane rich product gas in place of hydrogen (Eq. (4)). A catalyst (usually nickel based) is used to improve the reaction kinetics, which allows a lower reforming temperature and a reduction in the reactor size.

$$
\mathrm{CO}+3 \mathrm{H}_{2} \mathrm{O} \leftrightarrow \mathrm{CH}_{4}+\mathrm{H}_{2} \mathrm{O} \quad\left(\Delta \mathrm{H}_{298}=-206.28 \mathrm{~kJ} \cdot \mathrm{mol}^{-1}\right)
$$

The reactor design, in particular the integration of the catalytic combustor with the reformer, has a significant effect on reforming efficiency, system start-up time and 
transient response. This is particularly important in steam reforming since the endothermic nature of the reaction means that the rate of reformation is limited by the rate of heat transfer to the reactants [9]. In order to overcome the limitations of heat transfer in a traditional packed bed reactor there has been growing interest in the use of micro-channel heat exchanger technology as the basis of a compact steam reformer. These micro-channel reactors have been shown to outperform traditional reactor designs due to their increased rates of heat transfer to the catalyst and reactants and enhanced ability to control the reactor temperature [10, 11]. Another advantage of microchannel designs are the high values achievable for specific surface area. Micro-channel reactors can have specific surface areas of $10,000 \mathrm{~m}^{2} \mathrm{~m}^{-3}$ to $50,000 \mathrm{~m}^{2} \mathrm{~m}^{-3}$ compared to $100 \mathrm{~m}^{2} \mathrm{~m}^{-3}$ to $1,000 \mathrm{~m}^{2} \mathrm{~m}^{-3}$ for conventional reactors [12]. The use of micro-channel technology thus opens up the possibility of the use of wash-coated catalysts. Wash-coated catalysts have been shown to offer improved performance over a packed bed approach [13, 14] demonstrated the reduction in required contact time in a steam methane reformer by using a wash-coated micro-channel design.

Sulphur levels in the ppb range will deactivate most common nickel based reforming catalysts [15]. Since commercial grade LPG (and other fuels) unavoidably contains sulphur as an odorant, the sulphur needs to be removed from the fuel stream before it reaches the reformer catalyst and fuel cell. However rather than employing desulphurisation techniques, the use of sulphur tolerant catalysts may increase the flexibility of the system, opening up design alternatives which may improve efficiency, options for choice of feedstock, and reduce investments cost resulting in a lower cost of hydrogen $[16,17]$.

The interest of this research is to develop a compact microchannel reactor which is suitable for use with a sulphur tolerant catalyst for LPG steam reforming based on the technology of micro-channel heat exchangers. A hydrogen/air mixture to mimic the off gas available from a PEM fuel cell is used as fuel to the burner to supply the heat energy required. In practice, additional LPG would likely be required in addition to fuel cell off gas to supply sufficient heat required, though the amount would be dependent on the final system configuration and thermal integration. This is not something we can quantify as part of this work as a complete fuel processor would be required to evaluate the thermal integration and energy demand of the complete system, as such this information is not included in our paper.

\section{Multi-Function Compact Micro-Channel Reactor}

In this study, a new type of multi-function compact microchannel reactor has been developed based on shims technology. The reactor is formed of a central catalytic combustor layer sandwiched between two reforming layers as shown in Figure 1. 
The combustor layer is subdivided into air and fuel distribution sub-layers linked by a diffusion plate.

Each layer was built up from a number of shims stacked together as shown in Figure 2. The individual shims contain micro-openings and splitter bars. The micro-openings have widths of $1.10 \mathrm{~mm}$ and lengths of $5 \mathrm{~mm}$. The splitter bars contain grooves of $0.5 \mathrm{~mm}$ depth to help retain the catalyst. A number of shim designs were utilised each with an offset in position of micro-opening and splitter bar to the next. When the shims are placed on top of each other, the micro-openings align to produce microchannels that run the length of the stack and contain changes in the vertical plane in order to promote heat transfer and mixing of the reactants.

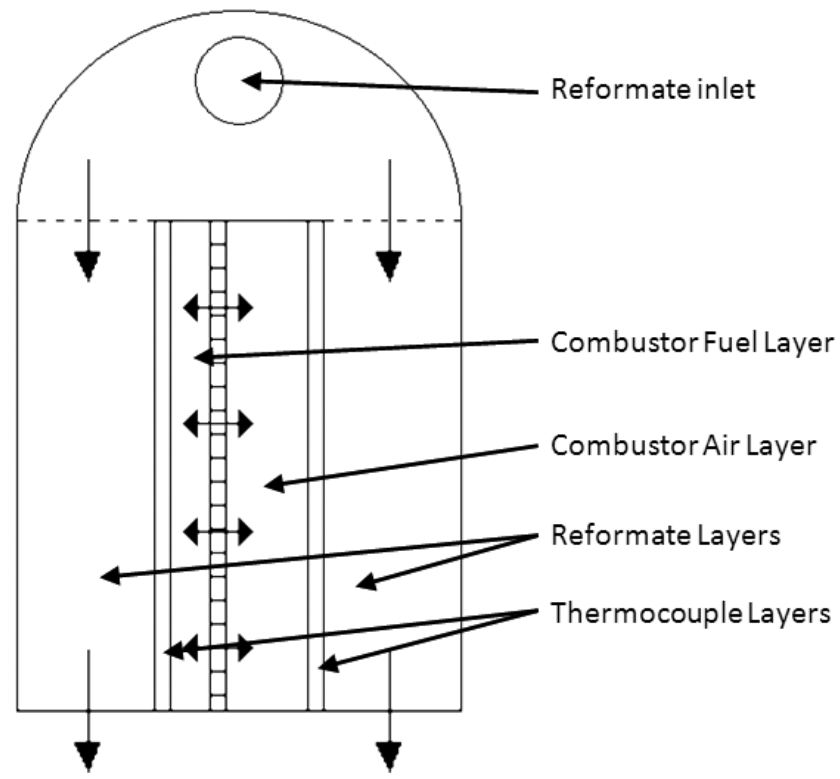

Figure 1: Internal structure of the micro-channel reactor

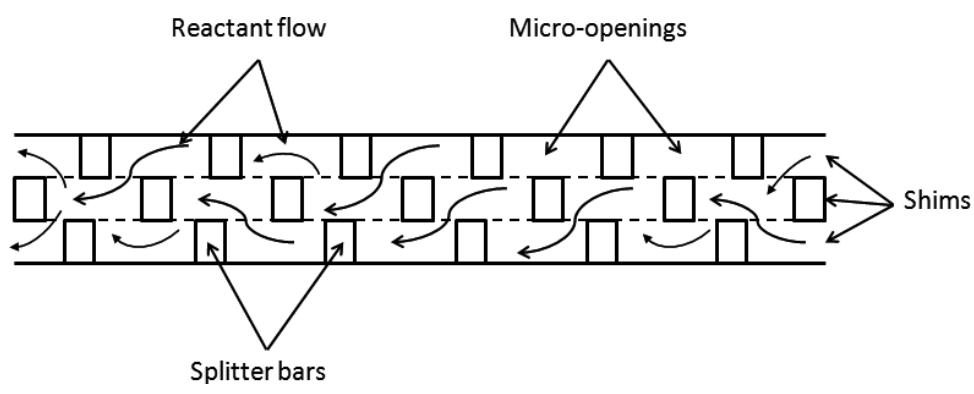

Figure 2: A stack of 3 shims showing the formation of a micro-channel

The different layers were then piled together to produce a multi-function reactor. In this case, the section with combustion function is sandwiched between the two sections with reforming functions, as showed in Figure 1. The heat generated by the combustion will then be efficiently transferred to the reforming sections to maintain the endothermic fuel reforming actions. Thermocouple ports were integrated into the reactor between the combustor and reforming layers to allow accurate temperature measurement and control of the reactor. The two reforming layers are joined at the inlet. The flow field through the reforming layer is straight through. This keeps the 
pressure drop across the reforming side to a minimum. The two reforming layers are made up of 8 groups of three shim designs producing 70 micro-channels across the width of the layer.

The combustor air sub-layer is similarly made up of eight groups of three shim designs, whilst the combustor fuel sublayer is made up of 2 groups of 3 different shim designs. The combustor fuel shims were designed and arranged so that four distinct zones each are formed inside the combustor fuel sub-layer along the length of the reactor as shown in Figure 3. Each combustor zone consists of 16 microchannels and has an individual fuel inlet. This allows the amount of fuel injected into each zone to be dynamically controlled to control the temperature profile of the reactor and avoid the formation of hot or cold spots. The combustor air sub-layer shims are machined so that the air flow passes along each of the combustor fuel zones in turn moving from zone 4 to zone 1 . The diffusion plate allows mixing of the fuel and air. The diffusion plate contains 64 holes, 16 holes per combustor fuel zone. These are aligned so that they link each fuel carrying micro-channel directly to a corresponding air carrying micro-channel. This facilitates the mixing of the combustion reactants whilst preserving the integrity of the combustion fuel zones. The combustion products are exhausted via the combustor air layer. To prevent internal cross over between the reforming and combustion layers separating plates are employed between them.

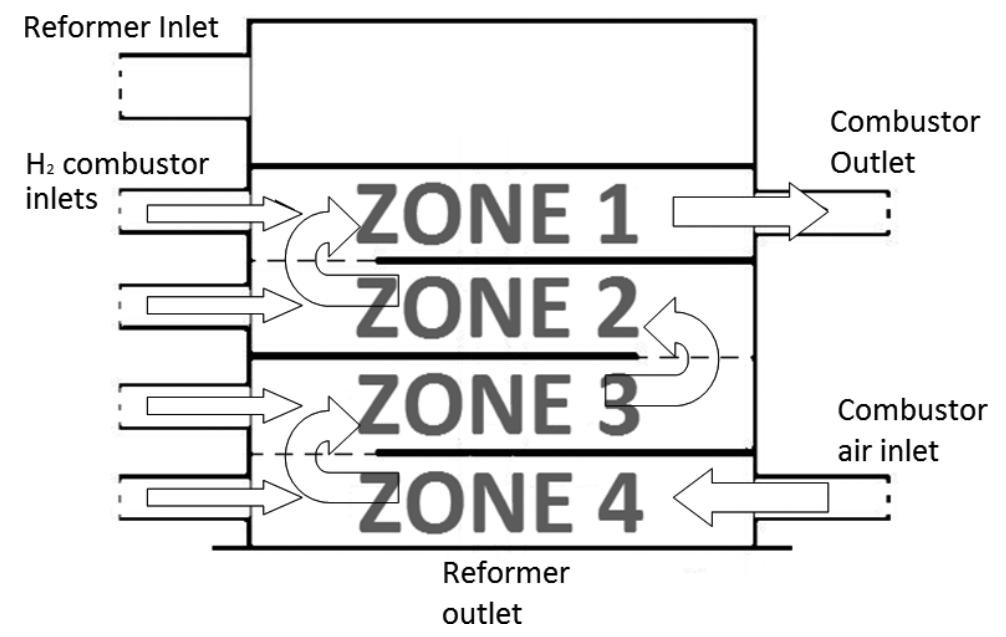

Figure 3: Combustion layer arrangement

The catalysts were developed and applied to the reactor using a wash-coating process by Catal International Ltd. The combustion catalyst used was composed of $0.3 / 0.1 \% \mathrm{Pt} / \mathrm{Pd}$ on alumina. The sulphur tolerant catalyst was composed of $0.15 \%$ $\mathrm{Ru}$ on $2.5 \% \mathrm{MgO} / \mathrm{Al}_{2} \mathrm{O}_{3}$. There was a $500 \mathrm{~W}$ pre-heater for the combustor air supply and a $750 \mathrm{~W}$ pre-heater for the LPG and de-ionised $\mathrm{H} 2 \mathrm{O}$ supply.

\section{Experimental Evaluations}


The test rig used to evaluate the compact micro-channel reactor for steam reforming performance is shown in Figure 4. There were three pipes inside the pre-heater for the LPG/ $\mathrm{H}_{2} \mathrm{O}$, one was used for the LPG and the other two for the $\mathrm{H}_{2} \mathrm{O}$. The reactants are mixed immediately after the pre-heater and before entering the reformer. The $\mathrm{H}_{2}$ to each zone of the combustor and the overall air supply to the combustor are operated using a closed loop control realised using National Instruments LabVIEW. This allows the reformer temperature to be controlled throughout the reformer (Reed et al., 2010). The combustor $\mathrm{H}_{2}$ /air mixture is controlled so as to mimic the proportion of $\mathrm{H}_{2}$ and $\mathrm{O}_{2}$ from typical fuel cell off gases to produce a mixture of $20 \% \mathrm{H}_{2}$ and $80 \% \mathrm{O}_{2}$ with the flow rate of $\mathrm{H}_{2}$ typically varying from $10 \mathrm{dm}^{3} \mathrm{~min}^{-1}$ at start-up to $4 \mathrm{dm}^{3} \mathrm{~min}^{-1}$ once operating. The excess $\mathrm{H}_{2} \mathrm{O}$ is condensed out of the reformate and the remaining gases are passed through online $\mathrm{CO}$ and $\mathrm{CO}_{2}$ (Siemens Ultramat 6) analysers before passing through a Pye gas chromatograph. The water was supplied using a computer controlled continuous flow syringe pump. The flow of LPG was manually controlled via a mass flow controller.

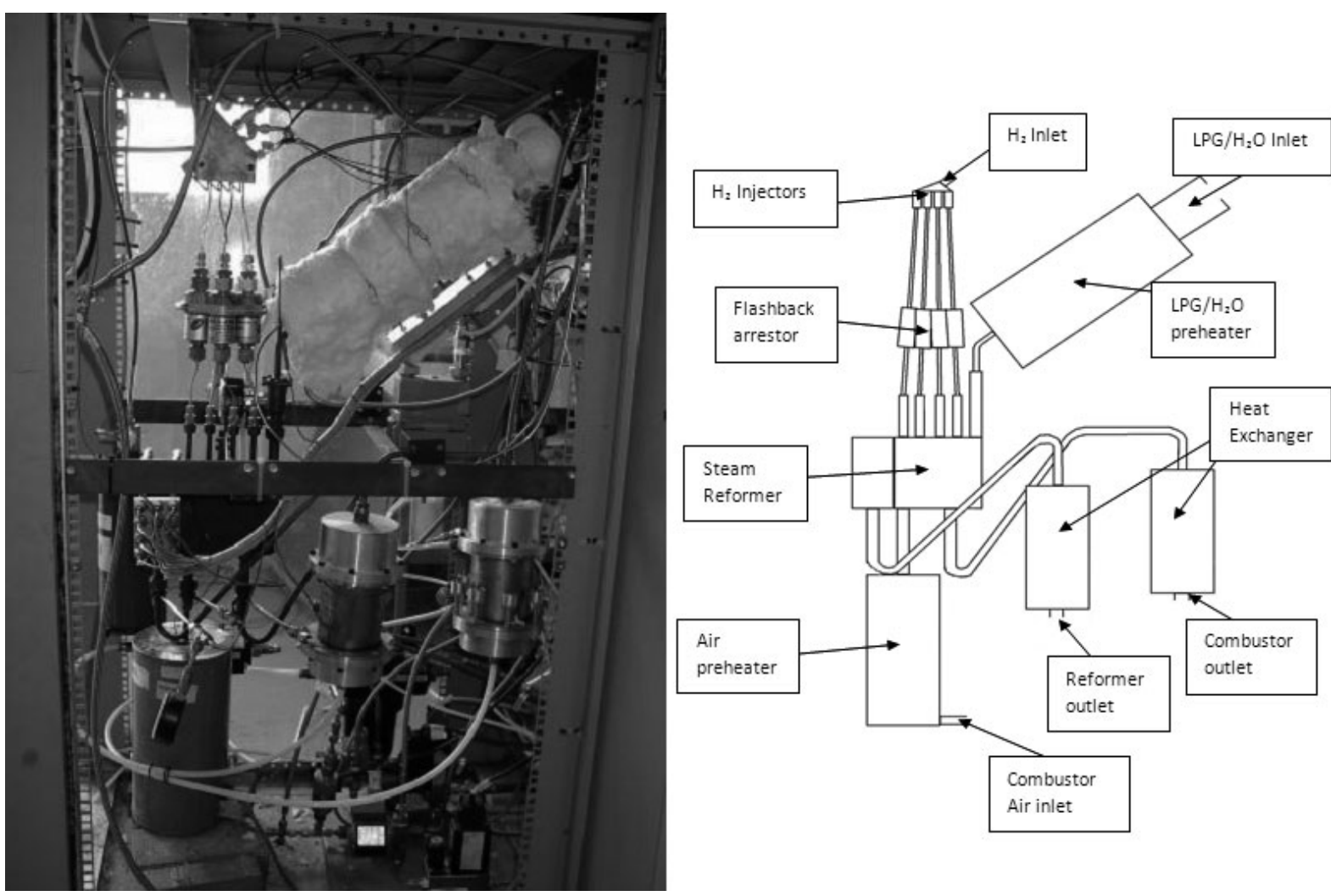

Figure 4: The test rig

During the study, the reformer was tested over a range of temperatures, steam to carbon ratios, and reactant flow rates. A commercial grade LPG supplied by Calor Gas Ltd., which contains sulphur compounds, was used as the reactant.

The test procedures were as follows:

- The temperature was set to the set-points of $723,773,823$ and $873 \mathrm{~K}$ whilst for each temperature the steam to carbon ratio was set to $2.5,3,3.5$ and 4 . 
- The flow rate of LPG was set at $0.75 \mathrm{dm}^{3} \mathrm{~min}^{-1}$ at standard temperature and pressure (STP) as this corresponds to approximately $0.5 \mathrm{kWe}$ (based on equilibrium data) from a fuel cell, given total conversion of the LPG.

- The set-point with the best performance was then chosen and the LPG flow rate was varied from 0.25 to $1.75 \mathrm{dm}^{3} \mathrm{~min}^{-1}$ (STP) whilst the temperature and S/C ratio were kept constant.

The catalytic combustor lights off at room temperature, so no additional heat was required to initiate warm-up. The reformer was then heated to $673 \mathrm{~K}$ with only $\mathrm{N}_{2}$ passing through the reforming side of the reactor. Both of the pre-heats were switched on throughout. This was to make sure that the inlet temperature was sufficiently high and that the $\mathrm{H}_{2} \mathrm{O}$ would vaporise on introduction. The reformer was then kept at a constant temperature of $673 \mathrm{~K}$ whilst the $\mathrm{H}_{2} \mathrm{O}$ was introduced. The amount of $\mathrm{H}_{2} \mathrm{O}$ was determined by the steam to carbon $(\mathrm{S} / \mathrm{C})$ ratio needed for the test set-point with a flow rate of $0.75 \mathrm{dm}^{3} \mathrm{~min}^{-1}$ (STP) of LPG. The reformer was kept at these running conditions until the temperatures stabilised. LPG was introduced at a S/C ratio of 8 and the temperature of the reformer was then increased to the desired set point. Once the desired temperature had been reached the LPG flow rate was increased gradually until the desired S/C ratio was reached.

The product gas from the reformer (i.e. the reformate mixture) was passed through two on-line analysers one for $\mathrm{CO}$ detection and the second for $\mathrm{CO}_{2}$ detection. A sample of the dry reformate mixture was also injected into the gas chromatograph in order that $\mathrm{H}_{2}$ and $\mathrm{CH}_{4}$ content could be determined. The results generated were the percentage composition of the dry reformate in molar units. The proportion of unconverted LPG was estimated as the balance of the sum of the reformer products.

\section{Results}

The measured effect of reformer temperature on dry reformate composition is shown in Figure 5. The LPG supply rate to the reformer was $0.75 \mathrm{dm}^{3} \mathrm{~min}^{-1}$ STP and the $\mathrm{S} / \mathrm{C}$ ratio was 4 during the test. It can be seen that as the reformer temperature increases so does the conversion of LPG. Over $60 \%$ of $\mathrm{H}_{2}$ composition can be achieved at high reforming temperatures. The increased conversion rate can be explained by the increase in energy provided to the reaction at higher temperatures. The increased conversion rate results in increased production of $\mathrm{H}_{2}, \mathrm{CO}_{2}$ and $\mathrm{CO}$. The production of $\mathrm{CH}_{4}$ is via methanation. It is interesting to note that the amount of methane decreases when the reactor temperature is above $773 \mathrm{~K}$. This is due to the reformation of the methane. 


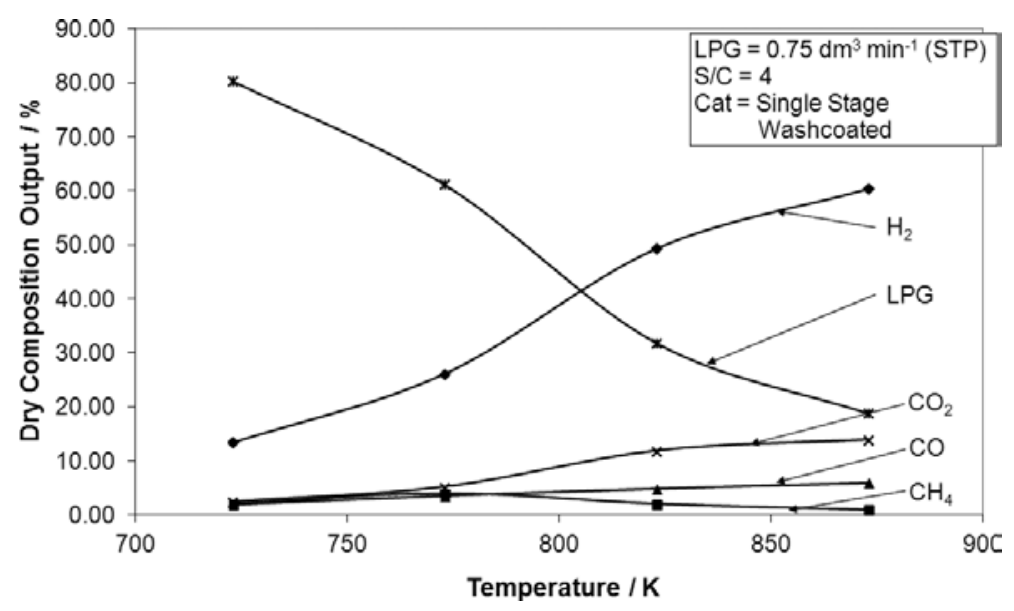

Figure 5: Measured dry reformate with a S/C of 4 at varying temperature

Figure 6 shows the calculated equilibrium dry products composition of steam reforming LPG at a S/C ratio of 4 with varying reactor temperature. It can be seen that the calculated results have the same trends as those measured, higher temperature results in increased hydrogen production. The calculated $\mathrm{H}_{2}$ concentration in the product is about $10 \%$ higher than the measured. The differences are due to the steam reforming reaction in the real reactor not having sufficient time to reach equilibrium. The methanation process that produces the $\mathrm{CH}_{4}$ in the equilibrium model is too slow to do the same in the actual reformer.

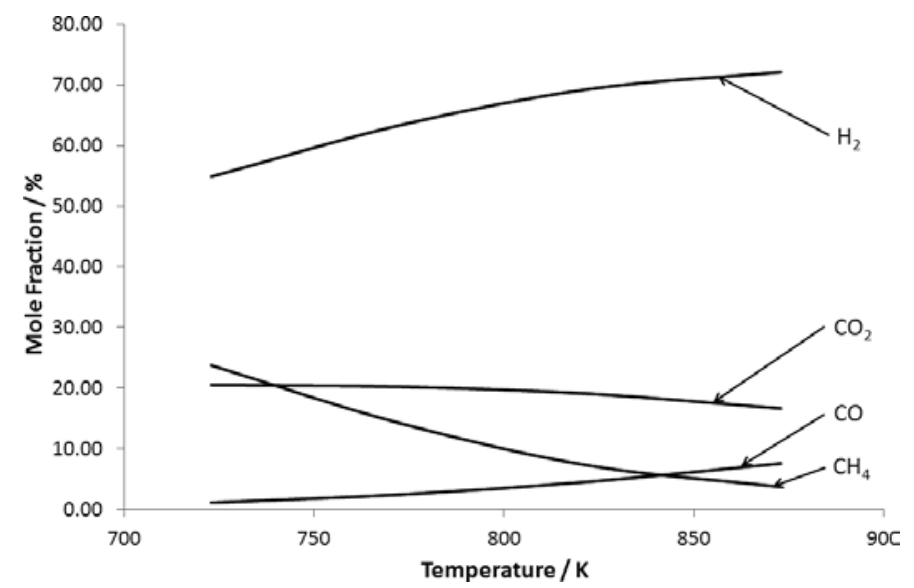

Figure 6: Calculated equilibrium dry reformat with a S/C ratio of 4 at varying temperature

The measured effect of the S/C ratio on the dry reformate composition is shown in Figure 7. During the test, the LPG supply rate to the reformer was $0.75 \mathrm{dm}^{3} \mathrm{~min}^{-1}$ (STP), and the reactor temperature was set to $873 \mathrm{~K}$. It can be seen that as the S/C ratio is increased so does the conversion of LPG. It increases the production of $\mathrm{H}_{2}$. In addition, the concentration of $\mathrm{CO}$ decreases whilst the amount of $\mathrm{CO}_{2}$ increases. The change in proportion of $\mathrm{CO} / \mathrm{CO}_{2}$ is due to the water shift reaction. Hydrogen from the water is liberated when the water reacts with the $\mathrm{CO}$ to produce $\mathrm{H}_{2}$ and $\mathrm{CO}_{2}$. 


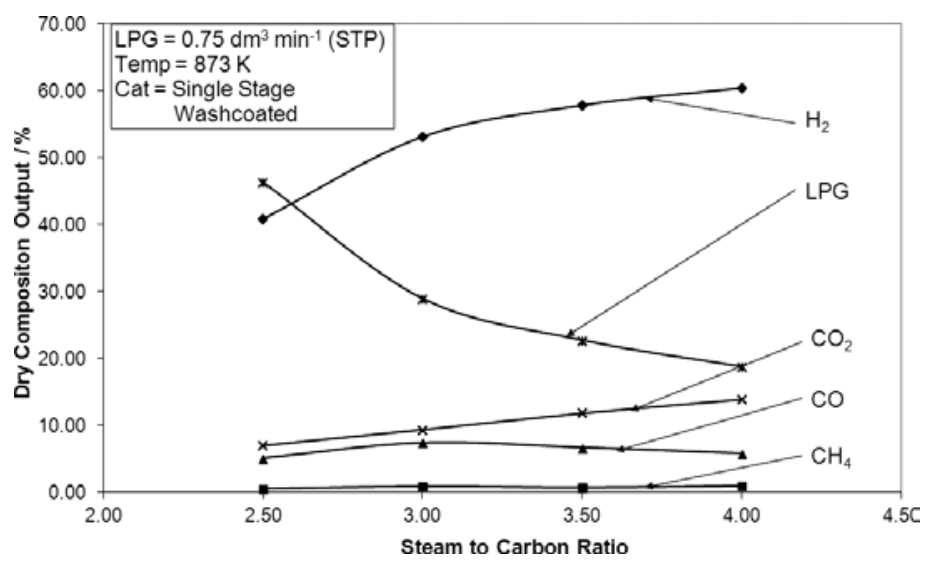

Figure 7: Measured dry reformate composition with varying S/C ratio at $873 \mathrm{~K}$

Figure 8 shows calculated equilibrium results of dry reformat composition with varying S/C ratio. In comparison with the measured results, it can be seen that with the exception of the percentage conversion of the LPG and the production of $\mathrm{CH}_{4}$ in the equilibrium results, the spread of values is similar. The maximum S/C investigated was four. This is twice the stoichiometric value. From simulated results it is clear that as long as the steam to carbon ratio increases, the amount of hydrogen produced will increase. However, it is more efficient to liberate this hydrogen, whilst removing carbon monoxide from the reformate in a separate lower temperature reactor. In this way the carbon monoxide content can be reduced to approximately $10 \mathrm{ppm}$ via preferential oxidation without the need for extra heat to be applied to the reformer [2]. Therefore, a steam to carbon ratio maximum limit of 4 was utilised.

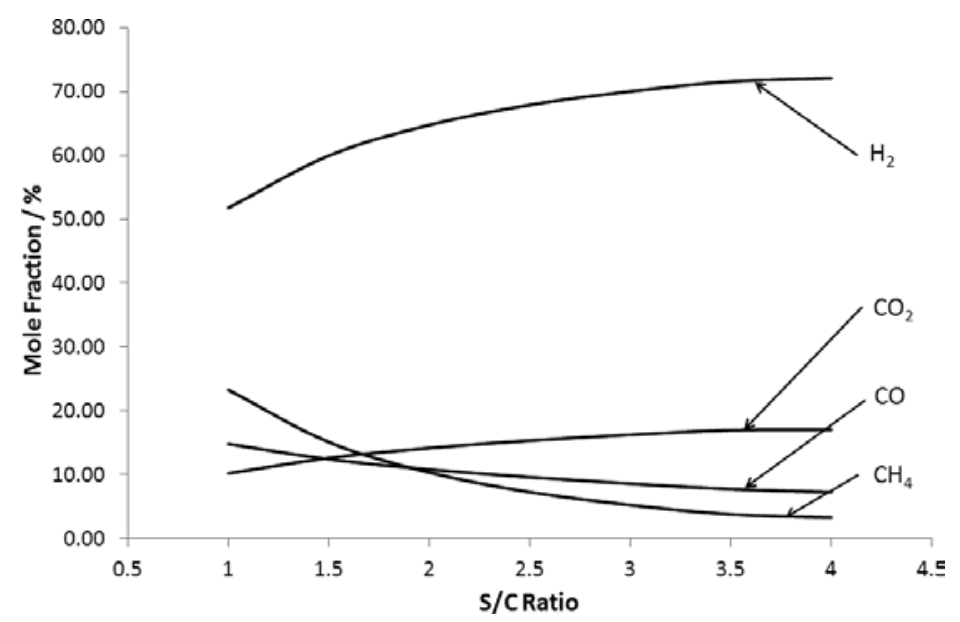

Figure 8: Calculated dry reformat composition with varying S/C ratio at $873 \mathrm{~K}$

The measured effect of the flow-rate of the reformer reactants on the dry reformate composition is shown in Figure 9. The S/C ratio during the test was 4 . The reactor temperature was set at $873 \mathrm{~K}$. It can be seen that as the flow rate of reactants to the reformer was increased the conversion of the LPG decreased. This is due to the reduction of residence time in the reformer itself. It suggests that the activity of the catalyst needs increasing for a reformer of this volume. This will be taken into account during the next stage of work. 
The energy conversion efficiency of the reformer can be defined as the ratio between the energy contained by the reformate products PLHV and the energy contained by the reactants RLHV,

$\eta=\frac{P_{L H V}}{R_{L H V}}$

The products in the efficiency calculation are the hydrogen and carbon monoxide produced. The reactants are the LPG to the reformer and the hydrogen to the combustor. It has been assumed that any hydrogen in the fuel cell off gas, which is approximately $1 / 3$ of the $\mathrm{H}_{2}$ to the stack, are burnt in the combustor. The energy used by the pre-heaters is not included in the calculation as this energy would be provided by heat exchangers in a complete fuel processor. Figure 10 shows the conversion efficiency of the reformer at different reactant flow rates with a S/C ratio of 4 and a reactor temperature of $873 \mathrm{~K}$. It can be seen that the average conversion efficiency of the reformer between 0.5 and $1.5 \mathrm{dm}^{3} \mathrm{~min}^{-1}$ (STP) is $59 \%$. The efficiency is low at low flow rates. At such low rates, the reformer is too big to operate efficiently due to the rate of heat transfer from the reactor to its surroundings. At an LPG flow rate of $1.75 \mathrm{dm}^{3} \mathrm{~min}^{-1}$ (STP), the efficiency decreases too, due to the $\mathrm{LPG} / \mathrm{H}_{2} \mathrm{O}$ preheat not being powerful enough to heat the reactants sufficiently to vaporise the $\mathrm{H}_{2} \mathrm{O}$ before it enters the reformer.

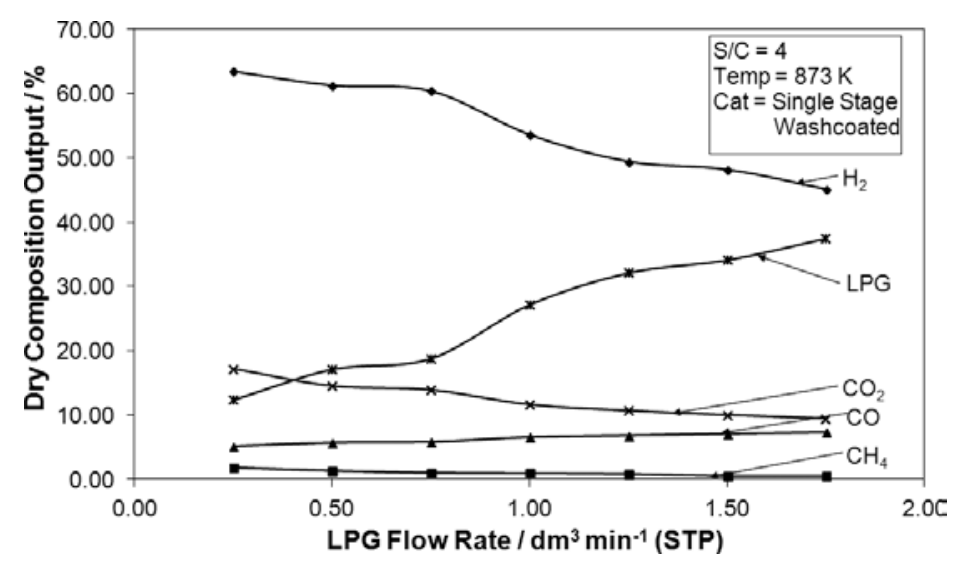

Figure 9: Measured dry reformat composition with varying reactant flowrate 


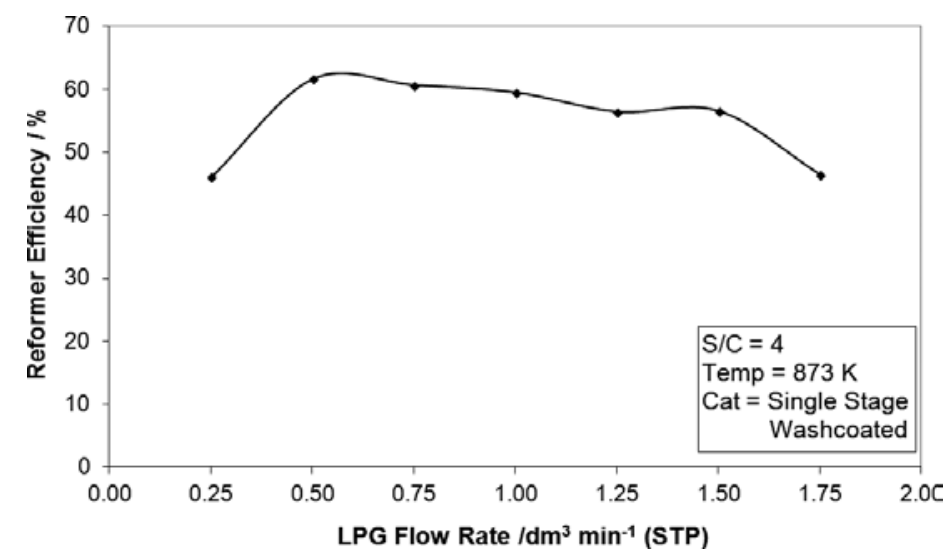

Figure 10: Reformer efficiency at varying reactants flow-rate

The power output of the reformer is based on calculated equilibrium data which was then modified according to the percentage conversion of the LPG feedstock as follows.

$P_{a}=\frac{C_{a} \times H \times 22.41}{F}$

where $P_{a}$ is the predicted power output from the fuel cell in $\mathrm{kWe}, C_{a}$ is the percentage conversion of the LPG, $H$ is the flow rate of hydrogen $\left(\mathrm{mol} \mathrm{min}^{-1}\right)$ produced at equilibrium by $1 \mathrm{~mol} \mathrm{~min}^{-1}$ of LPG for a given steam to carbon ratio and $F$ is the flow rate of hydrogen $\left(\mathrm{dm}^{3} \mathrm{~min}^{-1}(\mathrm{STP})\right)$ required to produce $1 \mathrm{kWe}$ output from a fuel cell. Figure 11 shows the effect of the reactants flow-rate on the predicted power output of a fuel cell. It can be seen that as the LPG flow rate increases the projected power output from the fuel cell increases. The maximum output achieved was $0.86 \mathrm{kWe}$ at an LPG flow rate of $1.75 \mathrm{dm}^{3} \mathrm{~min}^{-1}$ (STP) and S/C ratio of 4 and temperature of 873 $\mathrm{K}$. However, the conversion of LPG decreases with increasing LPG flow rate as shown in Figure 6 . When the power output reached $0.86 \mathrm{kWe}$ the conversion of LPG was only $62.5 \%$ which, would not be realistic for use in a complete system because of the additional processing required.

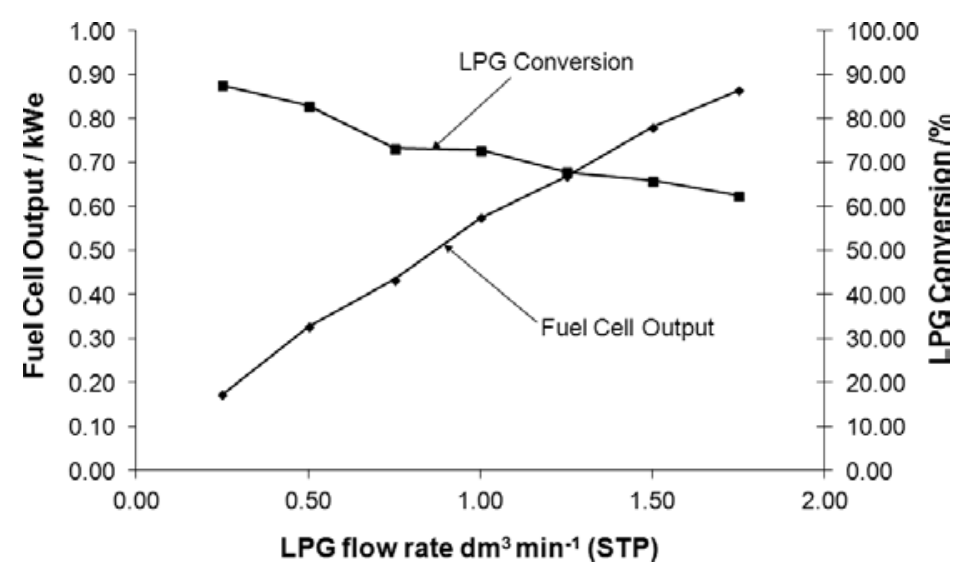

Figure 11: Predicted fuel cell power output at varying reactants flow-rate

Using the sulphur tolerant catalyst in this form, complete conversion cannot be achieved under any of the operating conditions tested. This will be addressed in 
future work with variations of the catalyst formulation. For this study space velocity is defined as the ratio of the volumetric flow rate of the feed stream to the volume of the coated channels of the reformer which is widely regarded as GHSV. The space velocity was found to be $5910 \mathrm{~h}^{-1}$ at a LPG flow rate of $1.75 \mathrm{dm}^{3} \mathrm{~min}^{-1}$ (STP) and steam to carbon ratio of 4 . The reformer was at a temperature of $873 \mathrm{~K}$.

\section{Conclusions}

- A multi-function compact chemical reactor designed for hydrocarbon steam reforming based on diffusion bonded laminate, micro-channel heat exchanger technology has been developed. This novel design offers accurately temperature distribution along the length of the reactor using closed loop temperature control.

- Experimental results showed that as the reformer temperature increases so does the conversion of LPG. Over $60 \%$ of $\mathrm{H}_{2}$ composition can be achieved at high reforming temperatures with a LPG supply rate of $0.75 \mathrm{dm}^{3} \mathrm{~min}^{-1}$ (STP) and a $\mathrm{S} / \mathrm{C}$ ratio of 4 .

- As the S/C ratio increases so does the conversion of $L P G$ which leads to increase in the production of $\mathrm{H}_{2}$.

- As the flow rate of reactants to the reformer increases, the conversion of the LPG decreases.

- The average conversion efficiency of the reformer between 0.5 and $1.5 \mathrm{dm}^{3} \mathrm{~min}^{-1}$ (STP) is $59 \%$.

\section{References}

[1] G. Upreti, D. L. Greene, K. G. Sawhney, Int. J. Hydrogen Energy 2012, 37, 6339.

[2] C. Dudfield, R. Chen, P. L. Adcock, J. Power Sources 2000, 85, 237.

[3] C. Mansilla, S. Avril, J. Imbach, A. Le Duigou, Int. J. Hydrogen Energy 2012, 37, 9451.

[4] M. Wichert, Y. Men, M. O'Connell, D. Tiemann, R. Zapf, G. Kolb, S. Butschek, R. Frank, A. Shiegl, Int. J. Hydrogen Energy 2011, 36, 3496.

[5] M. Grote, M. Maximini, Z. Yang, P. Engelhardt, H. Kohne, K. Lucka, M. Brenner, J. Power Sources 2011, 196, 9027.

[6] D. Di Bona, E. Janelli, M. Minutillo, A. Pema, Int. J. Hydrogen Energy 2011, 36, 7763.

[7] K.-R. Hwang, C.-B. Lee, S.-W. Lee, S.-K. Ryi, J.-S. Park, Int. J. Hydrogen Energy 2010, 36, 473. 
[8] J. M. Zalca, D. G. Lofflerb, J. Power Sources 2002, 111, 58.

[9] J. D. Holladay, J. Hu, D. L. King, Y. Wang, Catal. Today 2009, 139, 244.

[10] Y. Wang, Y. H. Chin, R. T. Rozmiarek, B. R. Johnson, Y. Gao, J. Watson, A. Y. L. Tonkovich, Catal. Today 2004, 98, 575.

[11] J. P. Reed, R. Chen, C. Dudfield, P. L. Adcock, Fuel 2010, 89, 949.

[12] L. Kiwi-Minsker, A. Renken, Catal. Today 2005, 110, 2.

[13] E. Simsek, A. K. Avci, Z. I. Onsan, Catal. Today 2011, 178, 157.

[14] A. L. Y. Tonkovich, B. Yang, S. T. Perry, S. P. Fitzgerald, Y.Wang, Catal. Today 2007, 120, 21.

[15] M. Ashrafi, C. Pfeifer, T. Proll, H. Hofbauer, Energy Fuels 2008, 22, 4190.

[16] F. Basile, S. Albertazzi, D. Barbera, P. Benito, J. Einvall, J. Brandin, G.

Fomasari, F. Trifir, A. Vaccari, Biomass Bioenergy 2011, 35, S116.

[17] C. Hulteberg, Int. J. Hydrogen Energy 2012, 37, 3978. 